In cooperation with the Wisconsin Department of Natural Resources and Ground-Water Resource Program

\title{
Soil Data at Sites near Geneva Lake, Lake Geneva, Wisconsin, and Long Lake, near New Auburn, Wisconsin
}

Open-File Report 2006-1191 


\section{Soil Data at Sites near Geneva Lake, Lake Geneva, Wisconsin, and Long Lake, near New Auburn, Wisconsin}

By David J. Graczyk and Steven R. Greb

In cooperation with the Wisconsin Department of Natural Resources and

Ground-Water Resource Program

Open-File Report 2006-1191 


\section{U.S. Department of the Interior DIRK KEMPTHORNE, Secretary \\ U.S. Geological Survey \\ P. Patrick Leahy, Acting Director}

\section{U.S. Geological Survey, Reston, Virginia: 2006}

For product and ordering information:

World Wide Web: http://www.usgs.gov/pubprod

Telephone: 1-888-ASK-USGS

For more information on the USGS - the Federal source for science about the Earth, its natural and living resources, natural hazards, and the environment:

World Wide Web: http://www.usgs.gov

Telephone: 1-888-ASK-USGS

Any use of trade, product, or firm names is for descriptive purposes only and does not imply endorsement by the U.S. Government.

Although this report is in the public domain, permission must be secured from the individual copyright owners to reproduce any copyrighted materials contained within this report. 


\section{Contents}

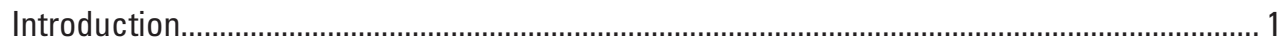

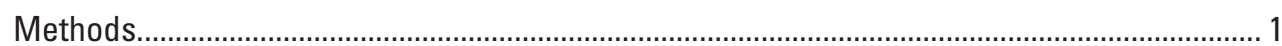

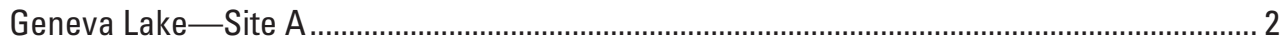

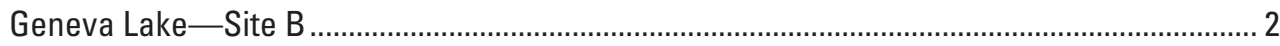

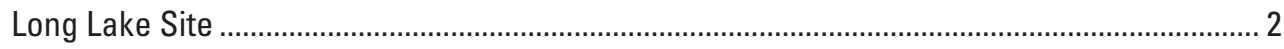

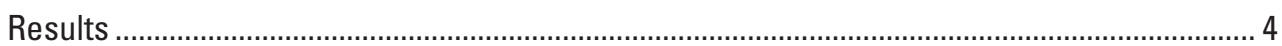

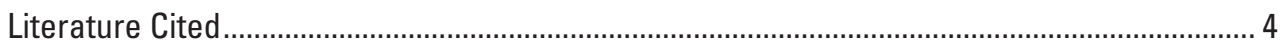

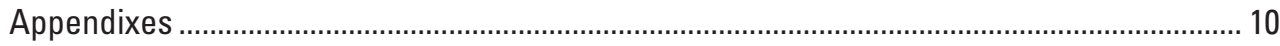

\section{Figures}

1. Map showing the location of study areas in Chippewa and Walworth counties, Wisconsin.....

2-3. Photos showing:

2. Typical site with lawn, lawn/woods interface, and wooded buffer ..................... 2

3. Soil-moisture probes at 10-centimeter, 20-centimeter, and 30-centimeter depths

4-6. Site maps for:

4. Site A at Geneva Lake, Lake Geneva, Wis. …….......................................... 3

5. Site B at Geneva Lake, Lake Geneva, Wis. ……........................................... 3

6. The Long Lake site near New Auburn, Wis.................................................... 4

7-11. Graphs showing:

7. Soil-moisture probe response to water application above the probes at Site A, Geneva Lake, Lake Geneva, Wis.

8. Water-content data during water application above the probes at Site B, Geneva Lake, Lake Geneva, Wis.

9. Water-content data during water applications above the probes at Site A, Geneva Lake, Lake Geneva, Wis., from August 10 to August 20, 2003.............. 7

10. Water-content data at Site B, Geneva Lake, Lake Geneva, Wis., from October 22 to November 7, 2003.

11. Water-content data at the Long Lake site near New Auburn, Wis., from May 18 to June 17, 2005 


\section{Conversion Factors and Abbreviated Units of} Measurement

\begin{tabular}{lll}
\hline \multicolumn{1}{c}{ Multiply } & \multicolumn{1}{c}{ By } & \multicolumn{1}{c}{ To obtain } \\
\hline & \multicolumn{1}{c}{ Length } \\
\hline inch (in.) & 2.54 & centimeter $(\mathrm{cm})$ \\
foot (ft) & 0.3048 & meter $(\mathrm{m})$ \\
\hline
\end{tabular}

Temperature in degrees Celsius $\left({ }^{\circ} \mathrm{C}\right)$ may be converted to degrees Fahrenheit $\left({ }^{\circ} \mathrm{F}\right)$ as follows:

${ }^{\circ} \mathrm{F}=\left(1.8 \times{ }^{\circ} \mathrm{C}\right)+32$ 


\title{
Soil Data at Sites near Geneva Lake, Lake Geneva, Wisconsin, and Long Lake, near New Auburn, Wisconsin
}

\author{
By David J. Graczyk and Steven R. Greb
}

\section{Introduction}

The goals of this project are to describe how water moves through shallow soil and how vegetated buffers influence this flow. This was accomplished by using a series of soil-moisture probes which track the lateral and vertical movement of water during natural and artificial rainfall/runoff events. The purpose of this report is to summarize soil-moisture data collected at near-shore areas adjacent to two Wisconsin lakes.

\section{Methods}

Figure 1 shows the locations of the two lakes, one in Walworth County, Wisconsin (Geneva Lake) and one in Chippewa County, Wisconsin (Long Lake). At each site, vertical shallow soil-moisture profiles were measured along transects that included an upslope lawn site, an intermediary vegetated buffer site and a downslope wooded site (fig. 2). The measurements were collected under natural rainfall conditions and controlled water additions. The soil-moisture probes were placed in a line parallel to the dominant hillslope, and traversed a lawn to a wooded buffer to determine both a vertical and horizontal movement of water. At each probe, soil moisture was monitored at $10 \mathrm{~cm}, 20 \mathrm{~cm}, 30 \mathrm{~cm}, 40 \mathrm{~cm}$ and $50 \mathrm{~cm}$ below the land surface (fig. 3). As recommended for most soil types (Sentek Pty Ltd, 1999), the probes were installed manually. An access tube hole was bored into the soil using a hand auger, through and slightly ahead of the access tube. The access tube was fitted with a cutting edge. The hand auger was placed into the access tube and soil inside was removed. The access tube was pushed down into the soil, providing a tight fit. A correct installation results in no air pockets along the length of the access tube and causes a minimal disturbance of the adjacent soil profile. The soilmoisture probe was inserted into the access tube. In addition, a tipping-bucket raingage was installed at each site to determine rainfall. At the Long Lake site, soil temperature was measured at 6 inches and 12 inches below the land surface in the lawn and in the wooded buffer.

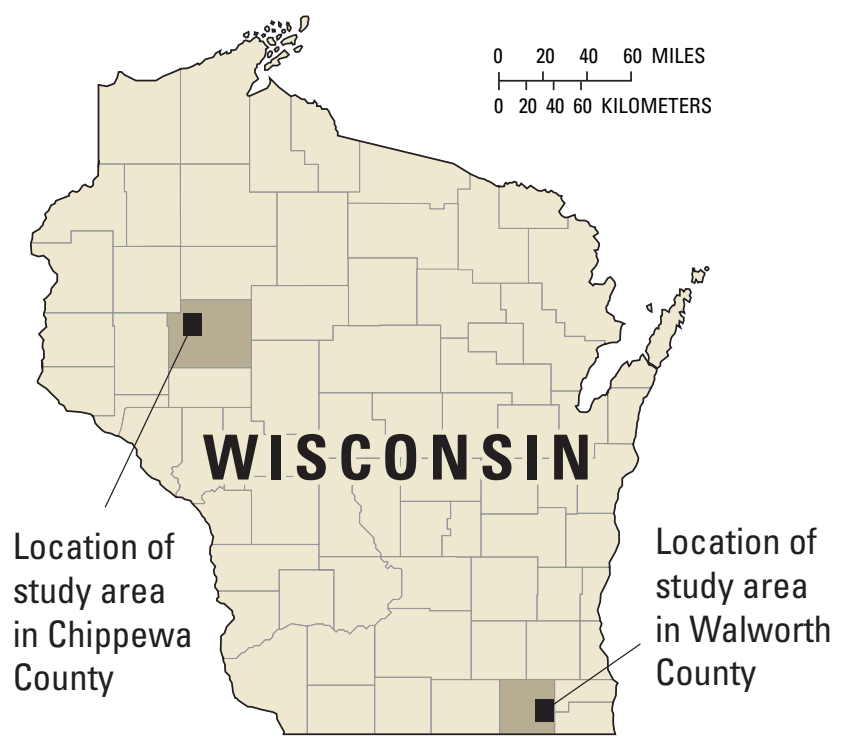

Figure 1. Map showing the location of study areas in Chippewa and Walworth counties, Wisconsin.

${ }^{1}$ Wisconsin Department of Natural Resources 


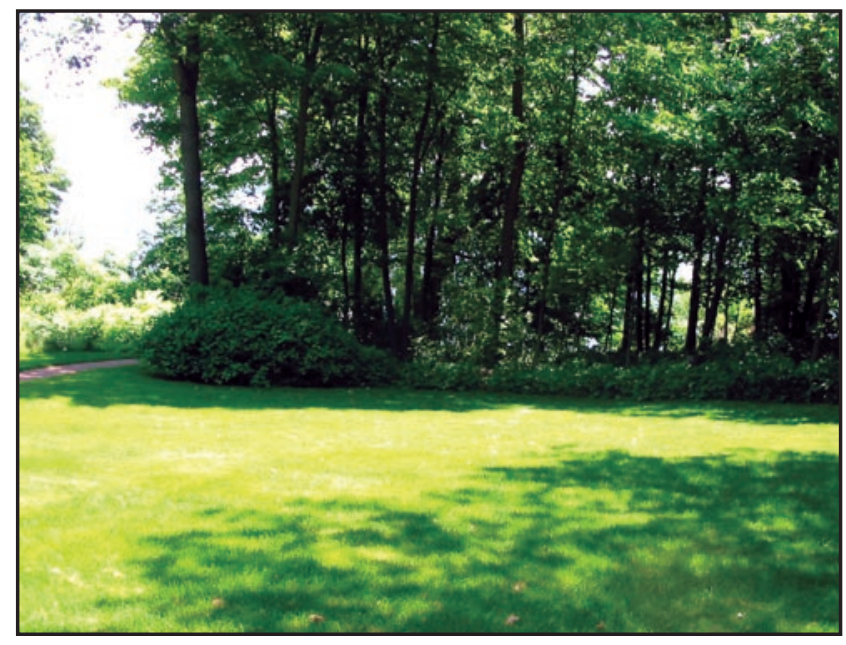

Figure 2. Typical site with lawn, lawn/woods interface, and wooded buffer.

\section{Geneva Lake-Site A}

Figure 4 shows the locations of the soil-moisture probes at Site A at Lake Geneva, Wis. Three soil-moisture probes were installed on August 3, 2003 and collected data until August 28, 2003. Probe 1 was installed in the lawn and received overland flow from the upgradient lawn, roof, and other impervious areas. Probe 2 was installed 25 feet downgradient from probe 1 and at the lawn/wooded buffer interface. The overland flow was predominantly from the upgradient lawn. Probe 3 was installed 25 feet downgradient from probe 2 and was installed in the wooded buffer. The overland flow to this site was a mixture of the lawn and wooded buffer. A tipping-bucket raingage was installed in between probe 1 and probe 2 on the lawn.

\section{Geneva Lake-Site B}

Figure 5 shows the locations of the soil-moisture probes at Site B at Lake Geneva, Wis. Three soil-moisture probes were installed on August 11, 2003 and collected data until November 6, 2003. Probe 1 was installed in the lawn and received overland flow from the upgradient lawn and rooftop. Probe 2 was installed 25 feet downgradient from probe 1 at the lawn/wooded buffer interface. The predominant overland runoff to this probe was from lawn runoff. Probe 3 was installed 25 feet from probe 2 in the wooded buffer and received mostly lawn and wooded buffer overland runoff. A tipping-bucket raingage was installed near probe 1 in the lawn.

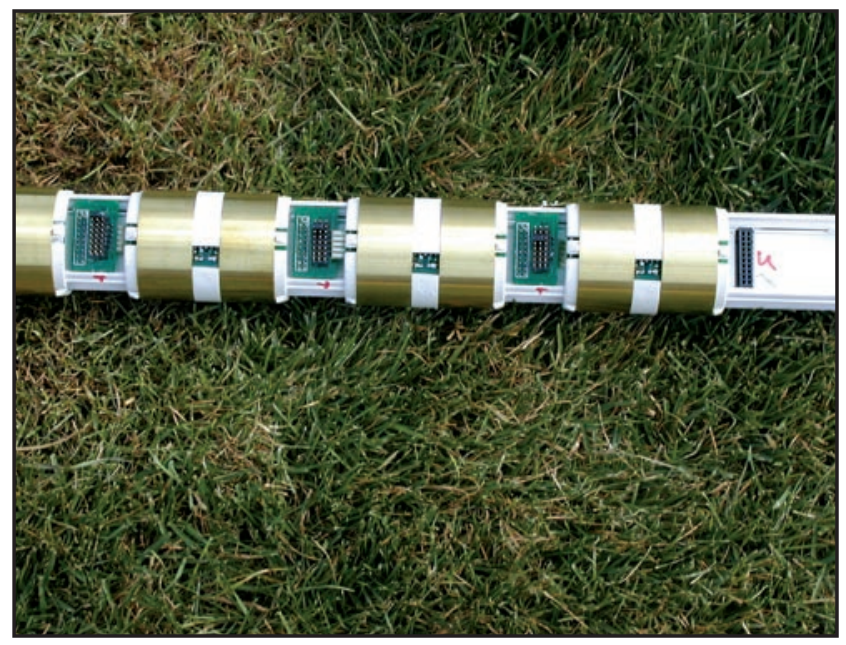

Figure 3. Soil-moisture sensors spaced at 10-centimeter intervals on soil probe.

\section{Long Lake Site}

The soil-moisture probes were installed at the Long Lake site from November 2004 to July 2005. Five soilmoisture probes, two soil-temperature probes and a tipping-bucket raingage were installed (fig. 6). Probe 1 was installed 12 feet downgradient from a downspout that drained a residential rooftop. Probe 2 was installed 10 feet down gradient from probe 1 in the lawn. The overland flow was from the rooftop and some lawn runoff. Probe three was 8 feet downgradient from probe 2 and at the lawn/ wooded buffer interface. Probe 4 was 14 feet from probe 3 and in the wooded buffer. Probe 5 was offset from the line of soil-moisture probes 1-4 and was 16 feet south of probe 2 and 15 feet southeast of probe 3 . The majority of the overland runoff is from the upgradient lawn. Near probe 5 in the lawn, a soil-temperature probe was installed. Soil temperature was measured at 6 inches below the ground surface and 12 inches below the ground surface. An additional soil-temperature probe was installed at the same depths in the wooded buffer near the soil-moisture probe 4. A tipping-bucket raingage was installed in the lawn near soil-moisture probe 5 . In addition, soil-temperature probes were installed 6 inches and 12 inches below the ground level in the lawn and in the wooded buffer. 
Site A. Geneva Lake, Lake Geneva Wis.

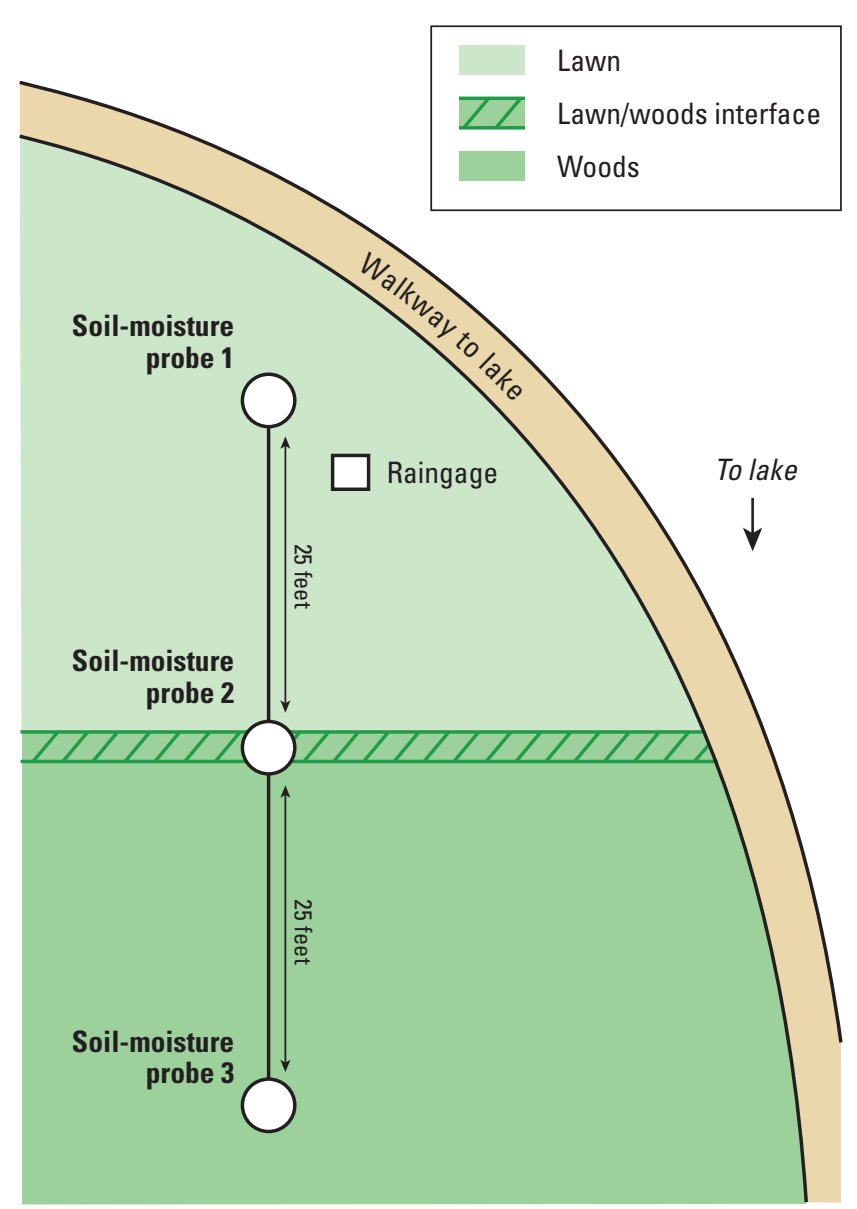

NOT TO SCALE

Figure 4. Site map for Site A at Geneva Lake, Lake Geneva, Wis.
Site B. Geneva Lake, Lake Geneva Wis.

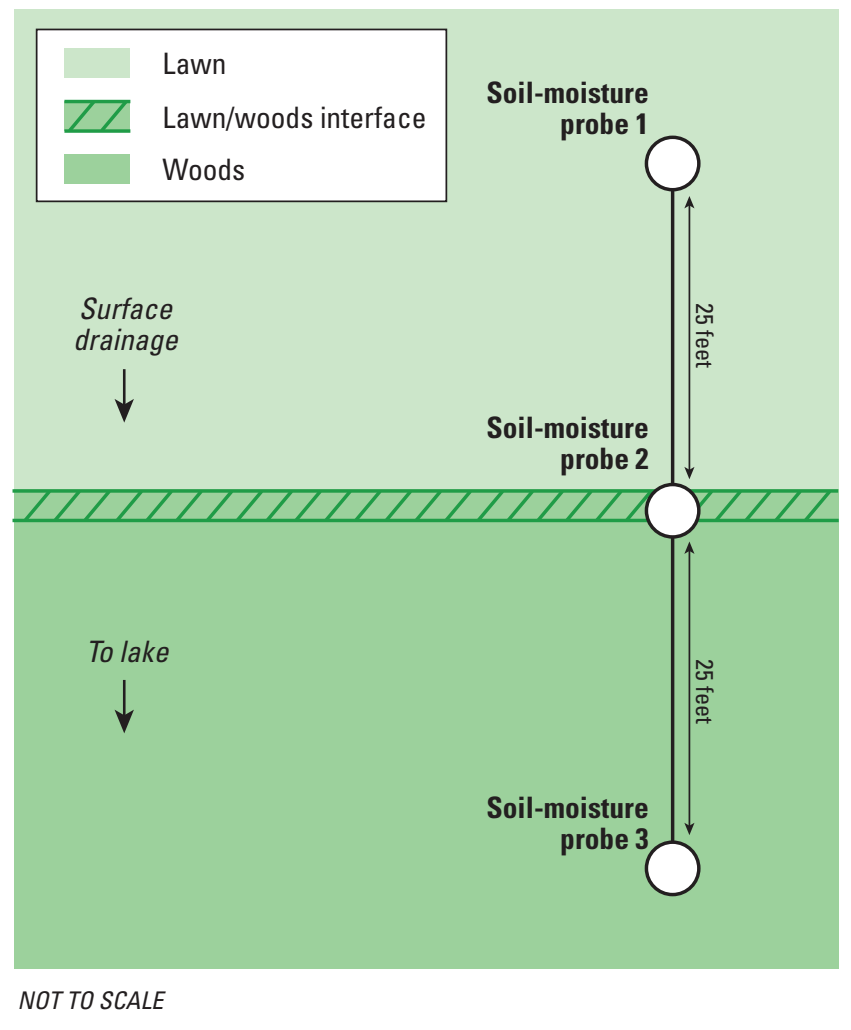

Figure 5. Site map for Site B at Geneva Lake, Lake Geneva, Wis. 


\section{Results}

A summary of all collected data is included in Appendix 1. Data showing precipitation from the tipping-bucket raingage at each site and the percent water content in the soil zone is included. At the two sites at Geneva Lake (Site A and Site B), water was applied to the transect to monitor the response in the shallow soil zone. Figures 7 and 8 report the volume and timing of water application, and show how the soil-moisture probes responded by adding water directly upstream of the probes.

Selected data plots for each site are also shown in figures 9 to 11 . The figures show the soil-moisture response to rainfall. Also, a summary of the soil-temperature data collected can be found in Appendix 2.

\section{Literature Cited}

Sentek Pty, LTD., 1999, Diviner 2000 Access Tube Installation Guide Version 1.0, 88p.

\section{Long Lake site, near New Auburn, Wis.}

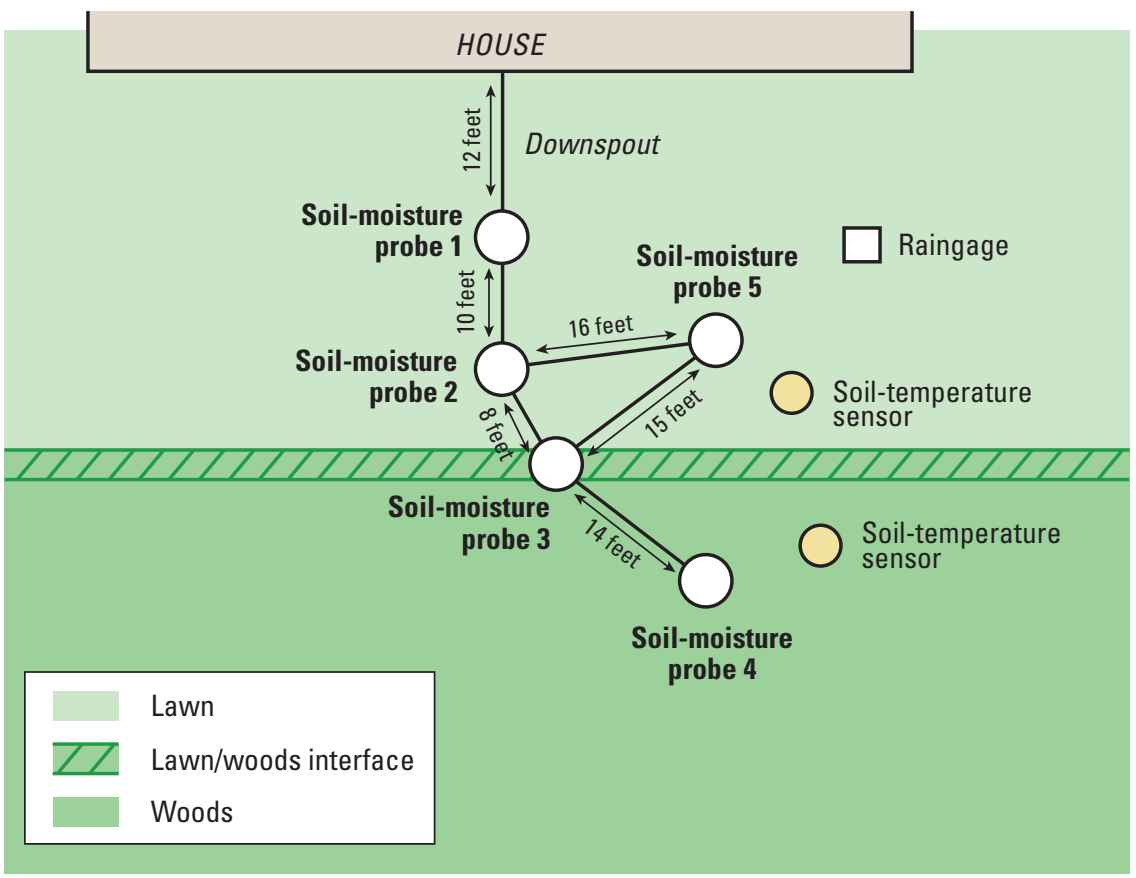

NOT TO SCALE

Figure 6. Site map for the Long Lake site near New Auburn, Wis. 

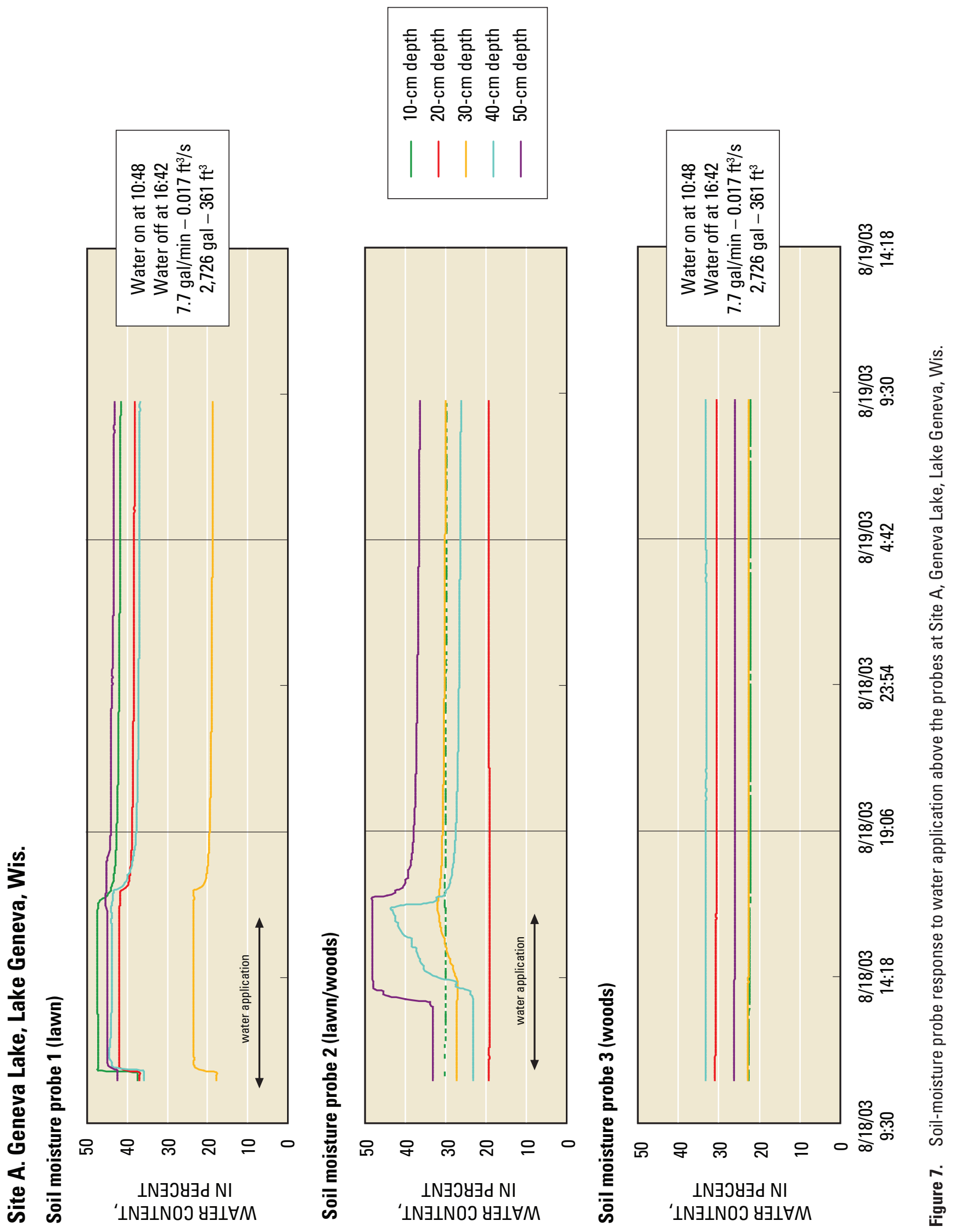

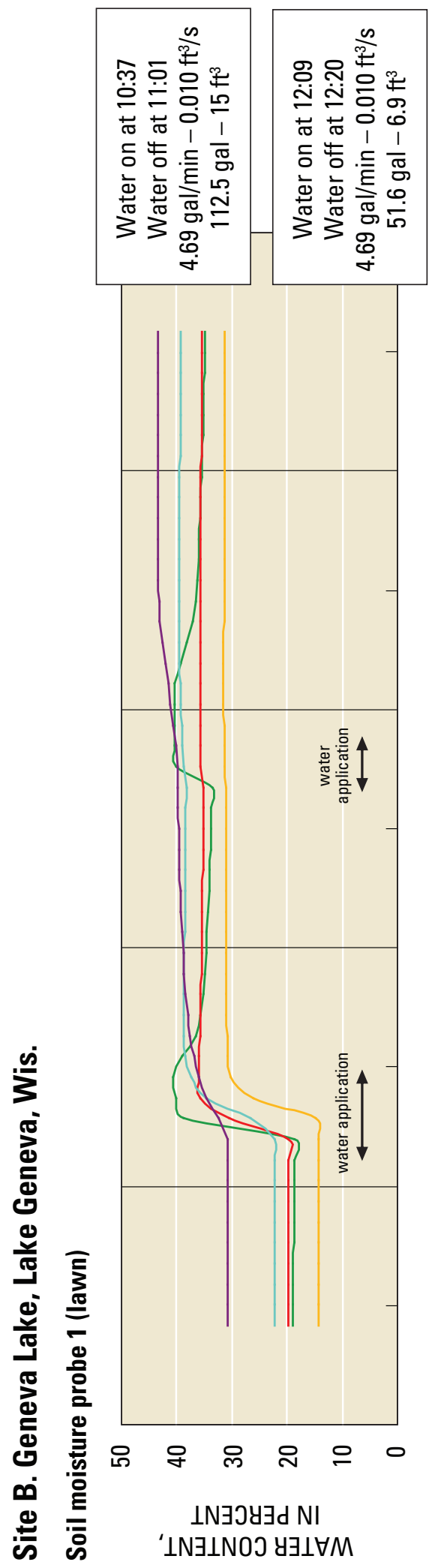
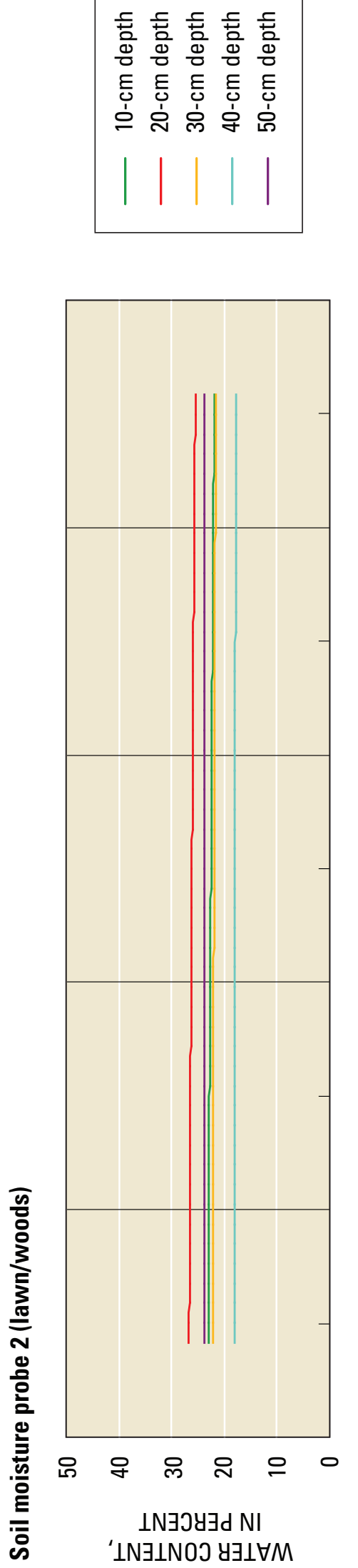

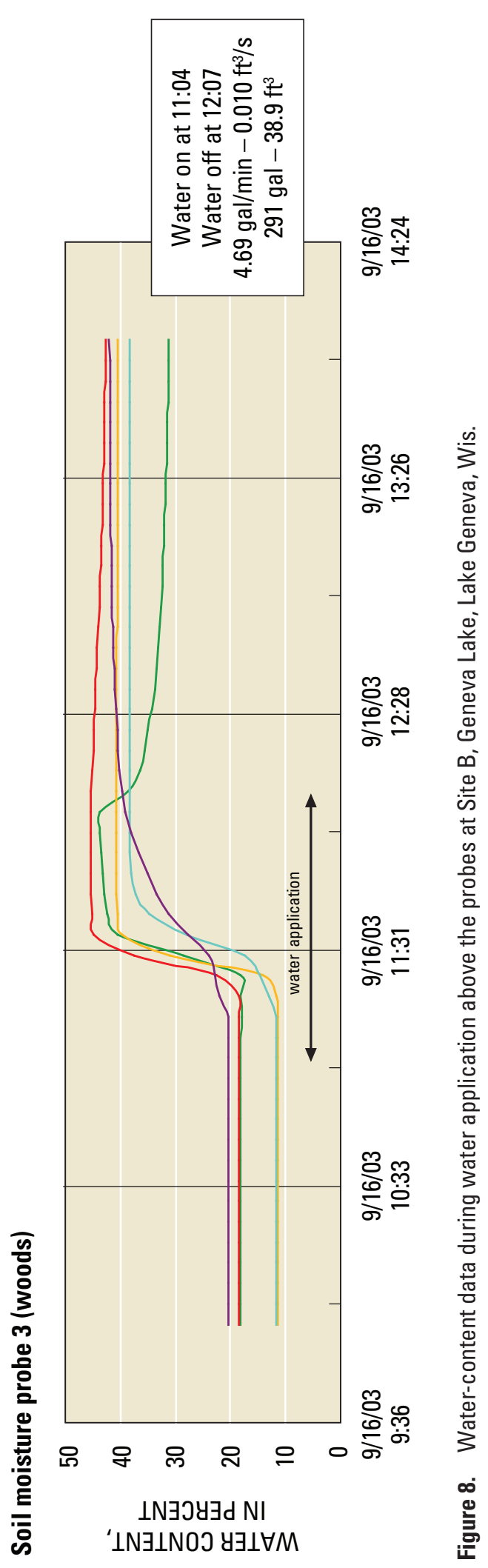




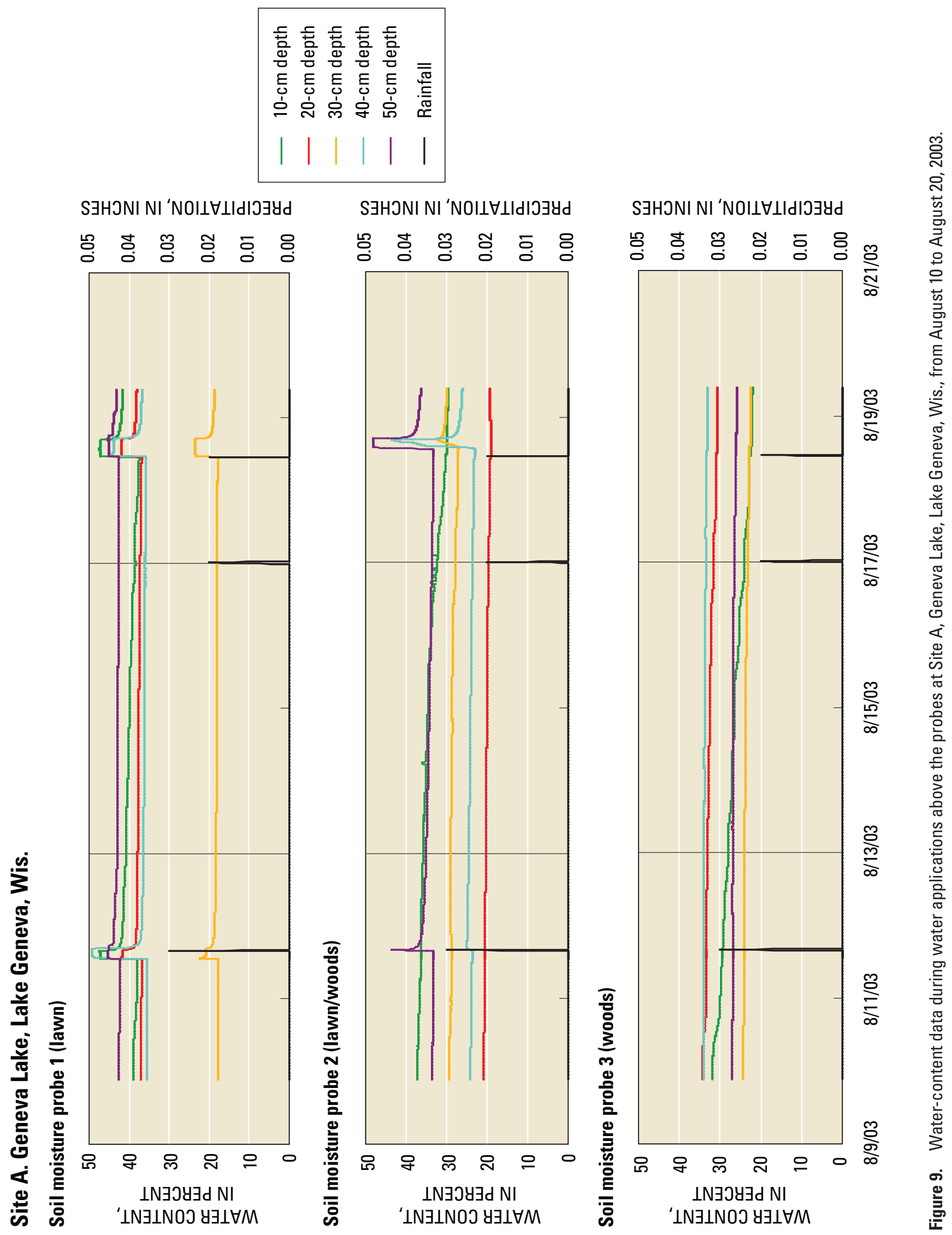



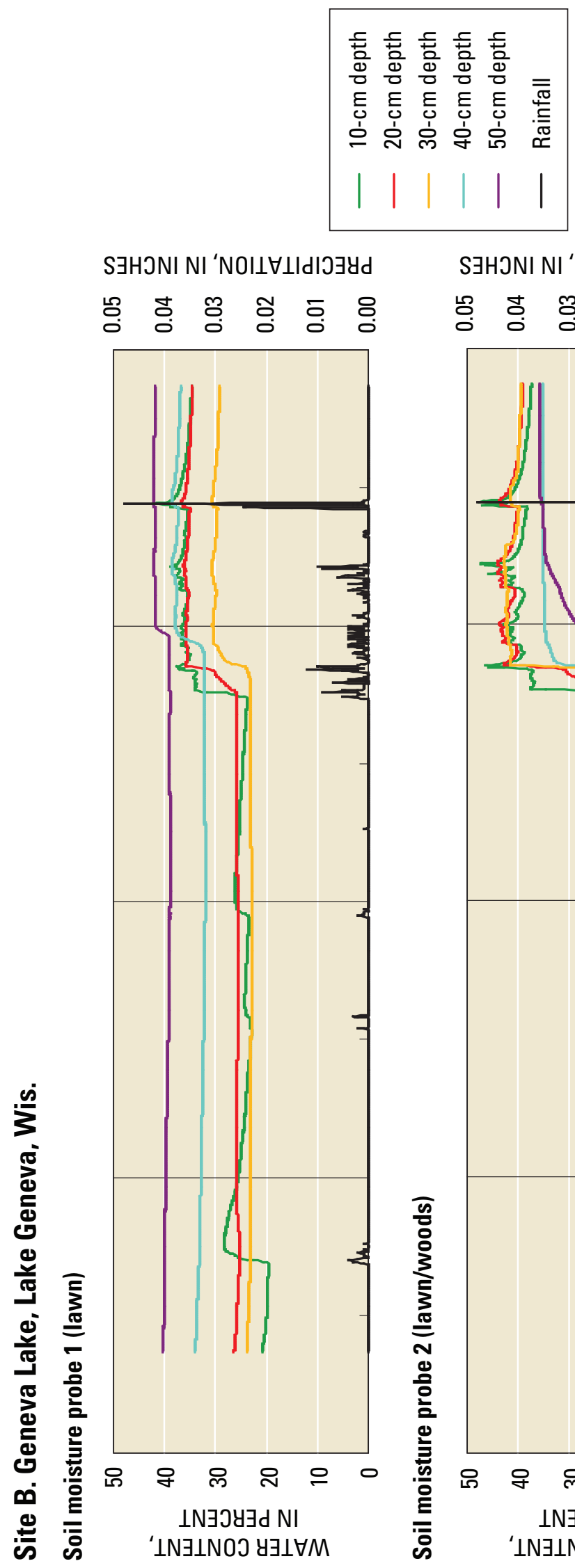

\section{SJHONI NI 'NOIL}

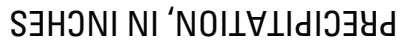

늉

늉 융
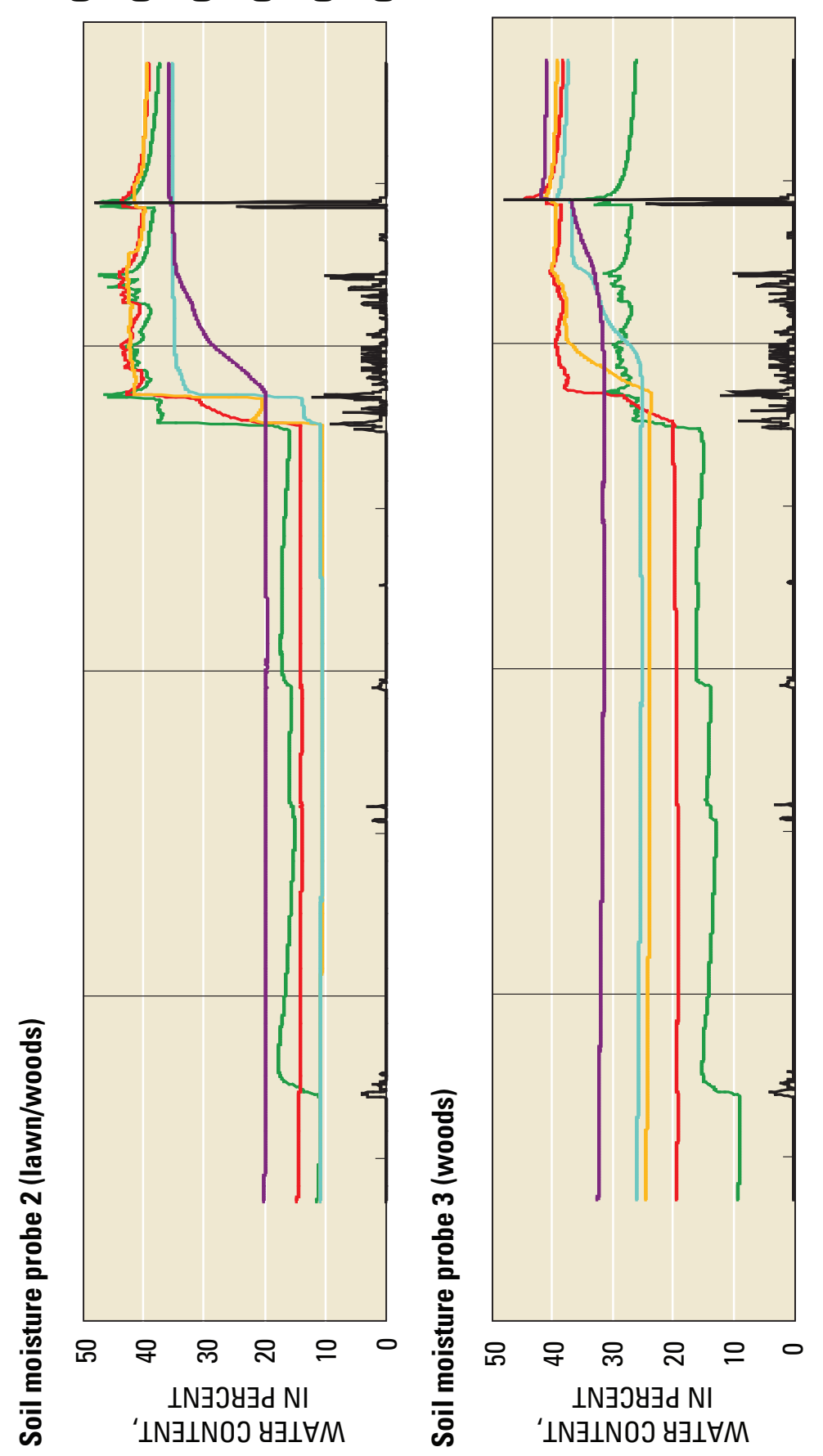

$\frac{\dddot{n}}{\stackrel{5}{=}}$

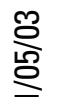

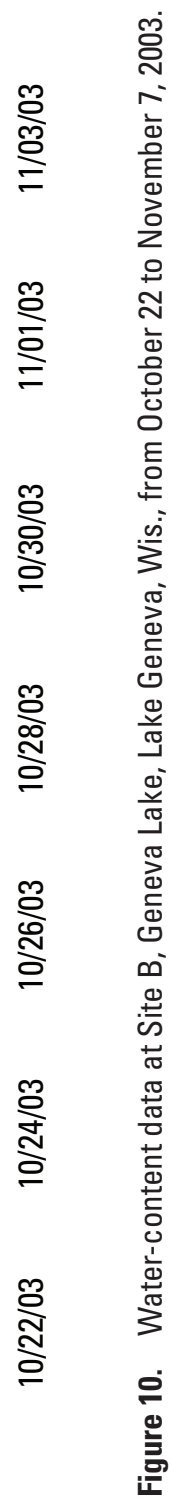

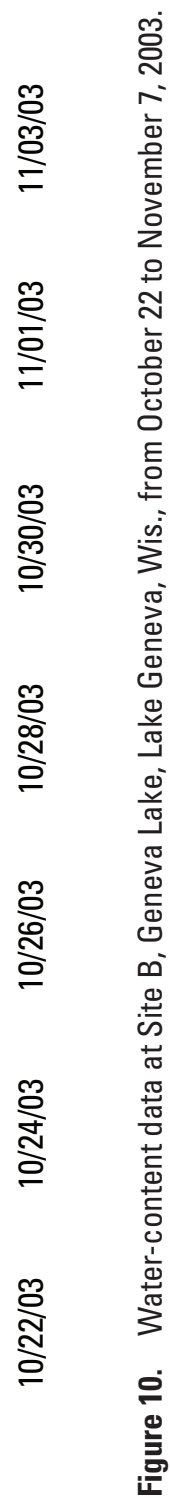


Long Lake site, near New Auburn, Wis.
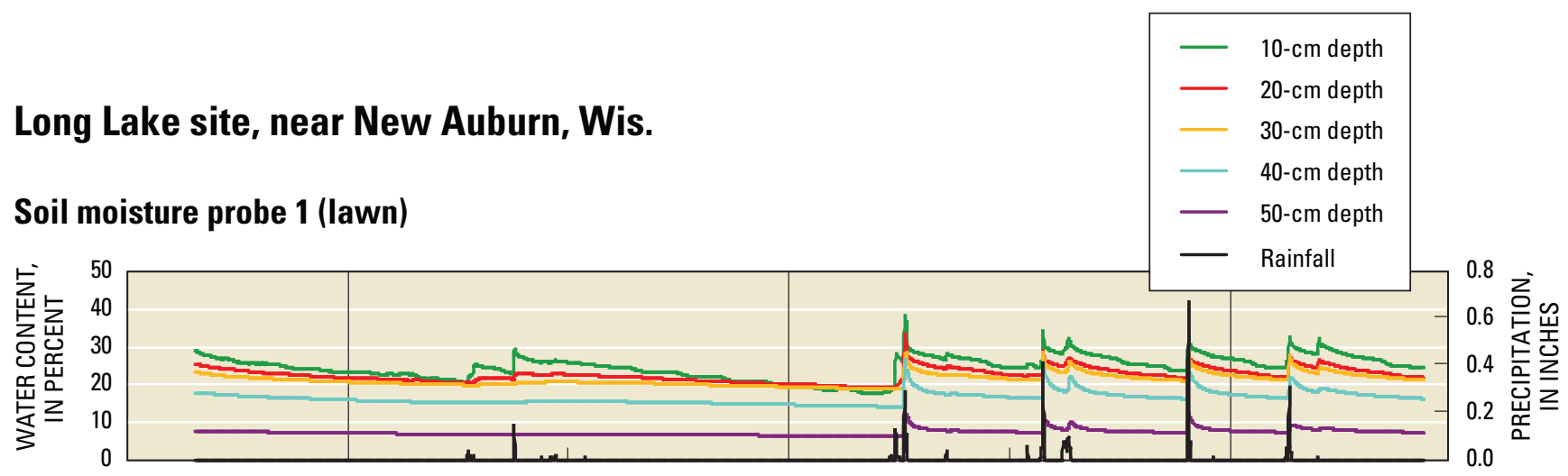

Soil moisture probe 2 (lawn)

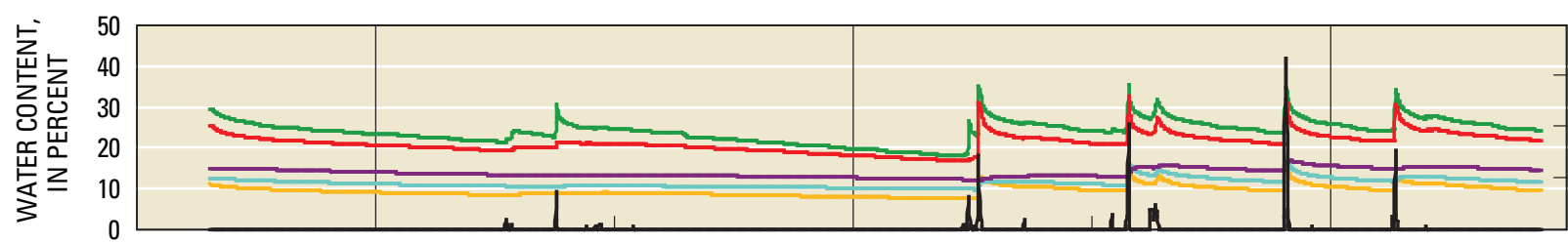

\section{Soil moisture probe 3 (lawn/woods)}

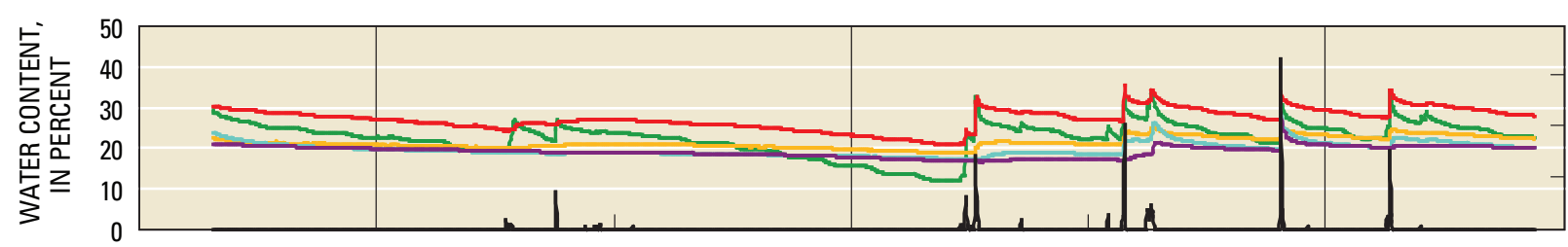

Soil moisture probe 4 (woods)

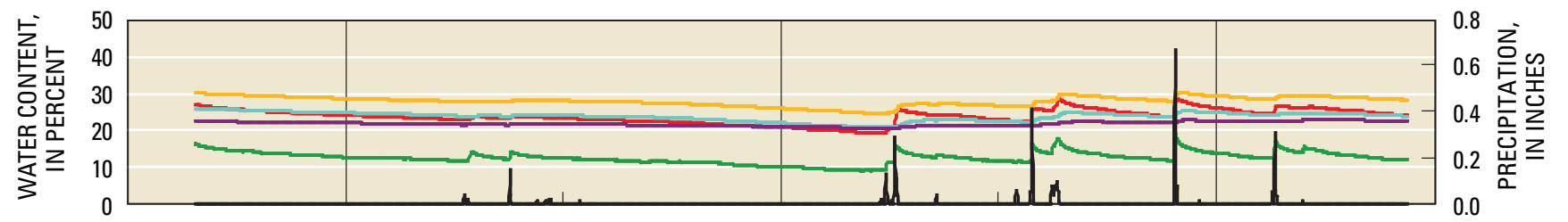

\section{Soil moisture probe 5 (lawn offset)}

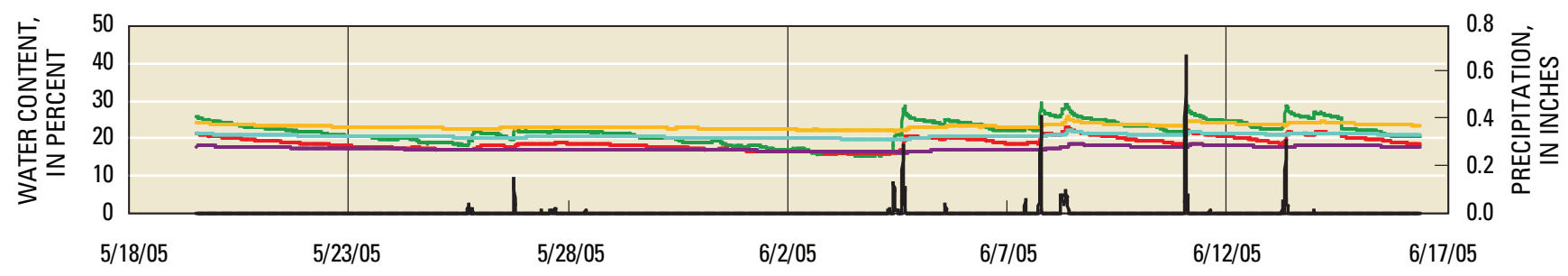

Figure 11. Water content data at the Long Lake site near New Auburn, Wis., from May 18 to June 17, 2005. 


\section{Appendixes}

The following appendixes can be downloaded from the online version of this report, available at $h$ ttp://pubs.water.usgs.gov/ofr2006-1191/

Appendix 1a. Summary of water content data collected at Site A at Geneva Lake, Lake Geneva, Wis., July 23, 2003 through August 28, 2003.

Appendix 1b. Summary of water content data collected at Site B at Geneva Lake, Lake Geneva, Wis., August 11, 2003 through November 6, 2003.

Appendix 1c. Summary of water content data collected at Long Lake, near New Auburn, Wis., August 19, 2004 through June 16, 2005.

Appendix 2. Summary of soil temperature at Long Lake, near New Auburn, Wis., August 27, 2004 through June 16, 2005. 